INTERNATIONAL JOURNAL OF RESEARCHES IN BIOSCIENCES, AGRICULTURE AND TECHNOLOGY (C) VISHWASHANTI MULTIPURPOSE SOCIETY (Global Peace Multipurpose Society) R. No. MH-659/13(N) www.vmsindia.org

\title{
EFFECT OF Al SUBSTITUENT ON STRUCTURAL AND ELECTRICAL PROPERTIES OF VANADIUM YIG
}

\author{
J.M. Khobragade ${ }^{1}$ and S.S. Darokar ${ }^{2}$ \\ Govt. Science College, Gadchiroli. (M.S) India. ${ }^{1}$ \\ Shivaji Science College, Nagpur -12 (M.S.), India. ${ }^{2}$ \\ jmkhobragade@gmail.com
}

\begin{abstract}
:
Substituted YIG with chemical formula $\mathrm{Y}_{2-\mathrm{x}} \mathrm{Bi}_{\mathrm{x}} \mathrm{CaFe}_{4.5-\mathrm{y}} \mathrm{AI}_{\mathrm{y}} \mathrm{V}_{0.5} \mathrm{O}_{12},(\mathrm{X}=0.5,1.0$ and $\mathrm{Y}=1.0$, 1.5) were prepared by standard ceramic technique and characterized by X-ray diffractrometry. Analysis of XRD revealed the presence of single crystalline phase with a space group Ia3d. The temperature variation of molar magnetic susceptibility was studied from room temperature to $800 \mathrm{~K}$. Most of the samples were found to be ferromagnetic with high Curie temperature and can be explained well. The variation of DC magnetic susceptibility and dielectric constant with temperature form room temperature to $700 \mathrm{~K}$ was also studied. For the composition $\mathrm{x}=1.0$ and $\mathrm{y}=1.0 ; 1.5$ the activation energy of conduction was found low as compared to the composition $\mathrm{x}=1.0$ and $\mathrm{y}=1.0$; 1.5. The dielectric constant was found to increase rapidly with temperature from $420 \mathrm{~K}$ to $600 \mathrm{~K}$.

Keyw ords: Garnet; magnetic susceptibility; electrical conductivity; dielectric constant.
\end{abstract}

\section{Introduction:}

In recent years Yttrium-ion garnet (YIG) and its substitutions have attracted many research worker due to their interestingly important applications in industry and technology. Amongst substituted YIG, bismuth-vanadate garnets have narrow resonance line width and are used in microwave (Goernert etal 1986),Magneto optical recording (Orkuda etal 1991), Solid state electronics (Bouwens 1987) and magnetic (Crangle 1977) devices.

Garnets have general chemical formula $\left\{\mathrm{X}_{3}\right\}$ $\left(Z_{3}\right) 0_{12}$, where the cautions $X$ occupy the dodecatiedral ( c ) sites with eight surrounding oxygens, while $\mathrm{Y}$ and $\mathrm{Z}$ occupy the octahedral (a) and tetrahedral (d) sites with six and four surrounding oxygens respectively (Rotmnan and Tuller 1987). The cubic unit cell of the garnet contains eight molecules and belongs to the space group Ia3d $\left(\mathrm{O}_{\mathrm{h}}{ }^{10-230}\right)$.The oxygen atoms occupy general $h$ positions characterized by three positional parameters $\mathrm{x}, \mathrm{y}$ and $\mathrm{z}$ (Geller eatal 1987). The point symmetries of the $c, a, d$ and $h$ sites are 222( $\left.D_{2}\right), 3(56), 4\left(S_{4}\right)$ AND $1\left(C_{1}\right)$ respectively ( international Tables for X-ray Crystallography (1967)

Ferrimagnetic garnets containing $\mathrm{V}^{+5}$ in combination with $\mathrm{Ca}^{+2}$ for electrostatics compensation have been reported by Geller et. al (1963) . The substation of $\mathrm{Bi}^{+3}$ reduce the preparation temperature of the polycrystalline iron garnets and $\mathrm{Al}+3$ substituted iron garnets. The $\mathrm{V}^{+5}$ ions having no sites preference energy, occupy d-sites, $\mathrm{Ca}+2$ and $\mathrm{Bi}^{+3}$ alongwith $\mathrm{Y}^{+3}$ occupy the c-sites (Chatterjee eatal 1978), while substitution of $\mathrm{Al}^{+3}$ ions for $\mathrm{Fe}^{+3}$ ions in YIG prefers tetrahedral d-sites. However, it has been observed that $\mathrm{V}^{+5}, \mathrm{Al}^{+3}$ and $\mathrm{Fe}^{+3}$ ions distribute themselves in both octahedral and tetrahedral sites (Geller eatal 1964; Rotman and Tuller 1987) cation ordering between $\mathrm{Fe}^{+3}$ and $\mathrm{Al}^{+3}$ has been reported previously to be present on a large scale in a silicate garnet giving rise to optical birefringence and reduction in symmetry from a cubic to an orthorhombic space group (Takeuchi and Haga 1976). Furthermore cation redistribution of $\mathrm{Fe}^{+3}$ and $\mathrm{Al}+3$ over the octahedral and tetrahedral sited is known to affect the magnetic, electrical, dielectric and other properties of the ferrite garnets[13] (Roschmann 1981)

The effect of substitution and distribution of the cations at different sites on the magnetic, electrical transport properties and kinetic of the synthetic garnet (Balestrino ansd Geller, Rotman and Tuller 1990, shanon etal 1991, salem and Elshereafy 1994) have been examined as they give information about the structure and other physical properties. Present study deals with the same combined effect of partial substitution of nonmagnetic $\mathrm{V}^{+5}$ and $\mathrm{Al}+3$ for $\mathrm{Fe}^{+3}$ ions in a and d-sites, and $\mathrm{Ca}+2$ and $\mathrm{Bi}^{+3}$ in $\mathrm{c}$-sites of the YIG.

\section{Experimental details: Sample preparation.}

Solid solution of the vanadium substituted YIG with composition $\quad \mathrm{Y}_{2-\mathrm{x}} \mathrm{Bi}_{\mathrm{x}} \mathrm{Ca} \mathrm{Fe} 4 \mathrm{y}$ $\mathrm{AI}_{\mathrm{y}} \mathrm{V}_{0.5} \mathrm{O}_{12},(\mathrm{x}=0.5,1.0$ and $\mathrm{y}=1.0,1.5)$ were prepared using solid state diffusion technique at atmospheric Pressure (Hellstrom etal 1989). AR grade oxides, $\mathrm{Y}_{2} \mathrm{O}_{3}, \mathrm{Bi}_{2} \mathrm{O}_{3}, \mathrm{CaO}, \mathrm{V}_{2} \mathrm{O}_{5}$ and $\mathrm{Fe}_{2} \mathrm{O}_{3}$ were mixed intimately in appropriate stoichiometric proportions and ground using AR grade acetone in an agate mortar. The mixture of the fine power was heated in air at the sintering temperature at $1000^{\circ} \mathrm{C}$ (Chatterjee etal 1978) for 60 hours in a muffle furnace and then cooled 
down at the rate of $800 \mathrm{C} /$ hour to room temperature. The polycrystalline sample thus formed was thenground for about half an hour for experimental investigation (Standley 1972).

\section{$\mathrm{X}$-ray diffraction analysis.}

X-ray diffraction pattern (XRD) for all the samples were recorded using Philips X-ray diffractometer with $\mathrm{Cu}-\mathrm{K}_{\mathrm{a}}$ radiation. XRD pattern of the sample showed a presence of single crystalline phase (Petrov etal 1987). The Patteren was analysed (Henry etal 1953) assuming the well settled space group Ia3d in which garnets are found (JCPDS-ICDD-1990). Figure 1 shows a typical XRD pattern of the garnet. Y $\mathrm{Bi} \mathrm{Ca}_{0.5} \mathrm{Al} \mathrm{V} 0.5 \mathrm{O}_{12}$. The Lattice parameter and $\mathrm{X}$-ray density of the specimen are included in the table. 1

Table -1. X-ray diffraction pattern of compound $\mathrm{Y}_{1} \mathrm{Ca} 0.5 \mathrm{Fe}_{3} \mathrm{Al}_{1} \mathrm{~V}_{0.5} \mathrm{O}_{12}$

\begin{tabular}{|c|c|c|c|c|c|c|}
\hline \multirow{2}{*}{$\begin{array}{l}\mathrm{S} \\
\cdot \\
\mathrm{N} \\
\mathrm{O}\end{array}$} & \multicolumn{2}{|c|}{ Sample } & \multirow{2}{*}{$\begin{array}{c}\text { Lattice } \\
\text { parame } \\
\text { ter } \\
a(\mathrm{AU})\end{array}$} & \multirow{2}{*}{$\begin{array}{c}\text { X-ray } \\
\text { densit } \\
y \\
d_{x} \\
(g m / c \\
c)\end{array}$} & \multirow{2}{*}{$\begin{array}{c}\text { Activati } \\
\text { on } \\
\text { Energy } \\
\text { Ea } \\
(\mathrm{eV})\end{array}$} & \multirow{2}{*}{$\begin{array}{c}\text { Dc } \\
\text { Conduc } \\
\text { tivity at } \\
300 \mathrm{k} \\
\left(\mathrm{ohm}^{-1}\right. \\
\left.\mathrm{cm}^{-1}\right)\end{array}$} \\
\hline & $\mathrm{x}$ & $\mathrm{y}$ & & & & \\
\hline 1 & 1.0 & 1.0 & $\begin{array}{c}12.34 \\
2\end{array}$ & $\begin{array}{c}5.49 \\
8\end{array}$ & 0.825 & $\begin{array}{l}-4.309 \\
\times 10^{-12}\end{array}$ \\
\hline 2 & 1.0 & 1.5 & $\begin{array}{c}12.32 \\
7\end{array}$ & $\begin{array}{c}5.41 \\
6\end{array}$ & 0.845 & $\begin{array}{l}-9.261 \\
\times 10^{-12}\end{array}$ \\
\hline 3 & 0.5 & 1.0 & $\begin{array}{c}12.33 \\
7\end{array}$ & $\begin{array}{c}5.08 \\
0\end{array}$ & 0.424 & $\begin{array}{r}-3.345 \\
\times 10^{-8}\end{array}$ \\
\hline 4 & 0.5 & 1.5 & $\begin{array}{c}12.27 \\
2\end{array}$ & $\begin{array}{c}5.05 \\
8\end{array}$ & 0.574 & $\begin{array}{c}-1.401 \mathrm{x} \\
10^{-11}\end{array}$ \\
\hline
\end{tabular}

$\mathrm{Y}_{2-\mathrm{x}} \mathrm{Ca}_{0.5} \mathrm{Fe}_{4-y} \mathrm{Al}_{\mathrm{y}} \mathrm{V} 0.5 \mathrm{O}_{12}$

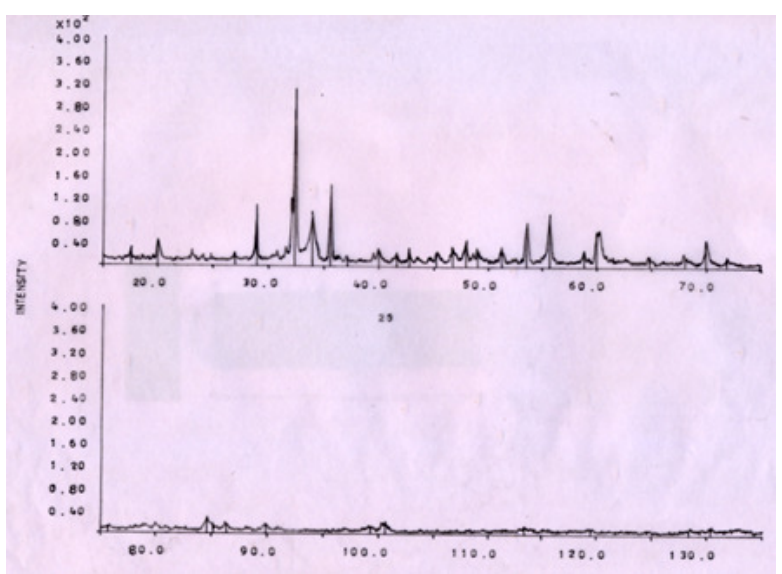

Fig. 1 : X-ray diffraction pattern of compound $\mathrm{Y}_{1} \mathrm{Ca}_{0.5} \mathrm{Fe}_{3} \mathrm{Al}_{1} \mathrm{~V}_{0.5} \mathrm{O}_{12}$

\section{DC electrical conductivity:}

The temperature dependence of the DC electrical conductivity was carried out from room temperature to $700 \mathrm{~K}$ by hot probe technique (Ramasastry etal 1971). For this the powder specimens were pelletized $(1.258 \mathrm{~cm}$ in diameter and about $0.2 \mathrm{~cm}$ thickness) at pressure of 5 tons per square $\mathrm{cm}$ using a hydraulic press. These prepared pellets were heated in a ceramic boat at $600^{\circ} \mathrm{C}$ for 3 hours and then cooled down to room temperature before the measurements of the conductivity. The opposite faces of the crack free and flat test pellets were coated with uniform thin layer of air-drying silver paste to ensure good electrical contacts with the brass electrodes. The variation of the DC electrical conductivity $\ln \sigma_{\mathrm{dc}}$ with the reciprocal of the temperature $10^{-3} / \mathrm{T} \mathrm{K}^{-1}$ is shown in figure 2 .
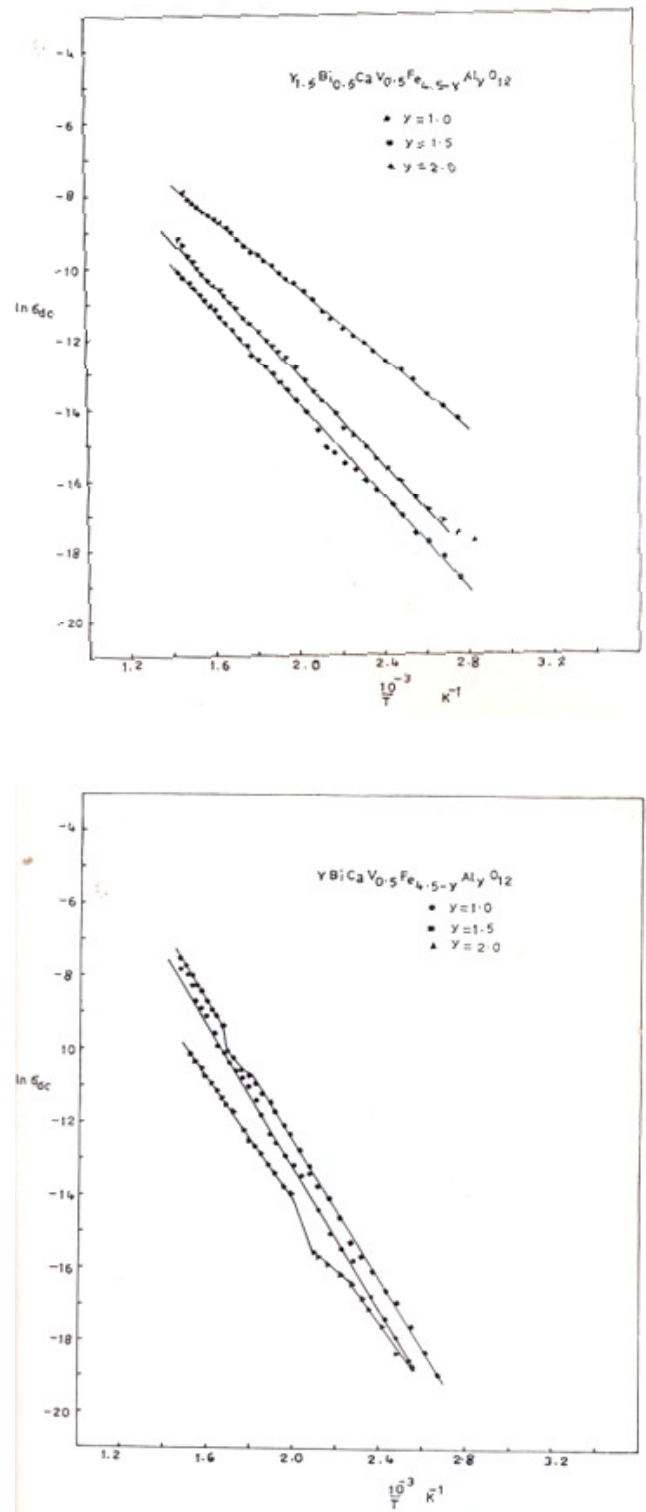

Figure 2: For Electrical Conductivity $\ln \sigma$ verses $1 / \mathrm{T} \times 10^{-3} \mathrm{~K}^{-1}$

\section{Dielectric Constant:}

The dielectric constant $\varepsilon^{\prime}$ as a function of temperature of the compositions were measured at frequency $1 \mathrm{KHz}$ from room temperature to 700K using parallel plate capacitance technique (Shanon etal 1991) by dsigital LCR meter (Model 
VLCR-17). The pelltes of the polycrystalline powder sample prepared for DC electrical conductivity were used for this purpose. The value of $\varepsilon$ ' were calculated without edge corrections. Figure -3 shows variation of $\varepsilon$ ' with temperature $\mathrm{T}$.

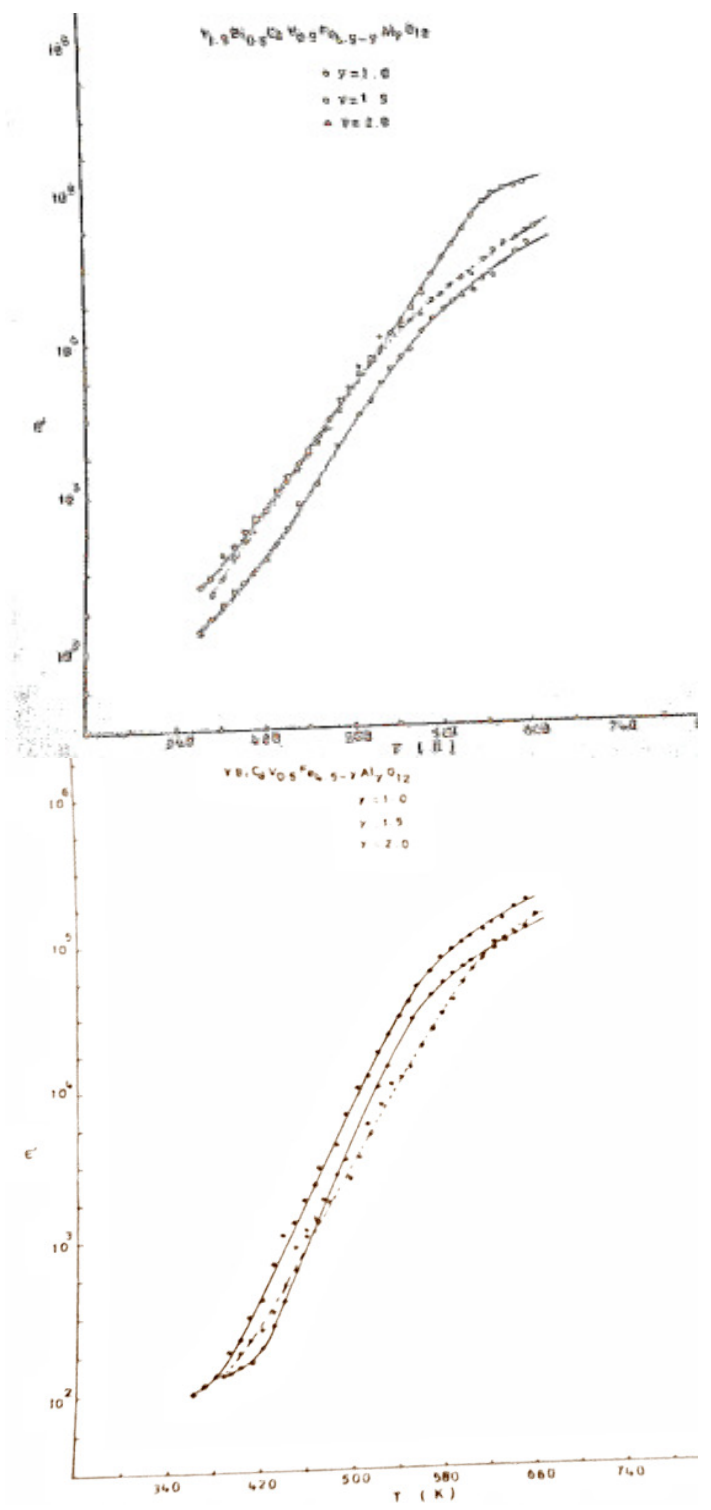

Figure 3 : Plot of dielectric constant $\varepsilon$ 'verses temperature $\mathrm{T}$

\section{Result and Discussion:}

The lattice parameter of $\mathrm{Y}_{3} \mathrm{FeO}^{12}$ and $\mathrm{Y}_{3} \mathrm{Al}_{5} \mathrm{O}_{12}$ is $12.3774 \mathrm{AU}$ and $12.0089 \mathrm{AU}$ respectively (JCPDS-ICDD-1990). The lattice constant and Xray density of the present series of sample (table 1) lies between the YIG and YAG. The size of the $\mathrm{Al}^{+3}(0.535 \mathrm{AO})$ and $\mathrm{V}^{+5}(0.54 \mathrm{AU})$ is smaller than $\mathrm{Fe}^{+3}\left(0.665 \mathrm{AU}\right.$ high spin state), while size of $\mathrm{Bi}^{+3}$ (1.03AU) is slightly more than $\mathrm{Ca}^{+2}(1.00 \mathrm{AU})$ and $\mathrm{Y}^{+3}(0.90 \mathrm{AU})$ ) (Shannon 1976). The $\mathrm{Bi}^{+3}$ ion in eight-fold coordinated c-sites increases the size of the unit cell of the garnet, but the substitution and distribution of $\mathrm{Al}^{+3}$ for $\mathrm{Fe}^{+3}$ by large amount in d-site than in $a$-site of YIG reduces the unit cell size (Langley etal 1979; Geller et.al 1964). Therefore it was expected to compensate the ionic sizes and do not affect large the size of the unit cell of the newly prepared garnets. The unit cell size are found to be closed to YIG itself. The trend of the decrease of the lattice parameter on substitution of $\mathrm{Al}+3$ and $\mathrm{V}^{+5}$ for $\mathrm{Fe}^{+3}$ in the substituted YIG is found to be in agree with the results of Geller etal (1964).

From the plot of $\ln \sigma_{\mathrm{dc}}$ versus $10^{-3} / \mathrm{T} \mathrm{K}^{-1}$, the value of activation energy $\left(\mathrm{E}_{a}\right)$ of $\mathrm{dc}$ conduction were calculated and are listed in table 1. It is known that pure YIG is an ionic crystal having room temperature conductivity bellow $10^{-3} \mathrm{ohm}^{-1} \mathrm{~cm}^{-1}$ (Hartmann etal 1984) and substituted YAG show a mixed ionic-electronic conductivity (Rotman and Tuller 1987). In the present work, the curves are slightly distorted hear to the ferromagnetic curie temperature expect the sample 3 . The activation energy is found to rise by increasing $\mathrm{Al}^{+3}$ for $\mathrm{Fe}^{+3}$ or by reducing the concentration of $\mathrm{Bi}^{+3}$ by $\mathrm{Y}^{+3}$, by $50 \%$, there is approximately same reduction in the activation energy. This could be attributed to a presence of transition metal ions in two or three sub lattices which forms an extra complications for the explanation of the conductivity (Metselaar and Larsen 1987). In the vanadium garnets, there may be columbic effect interaction which dominate the charge transport behavior (Oversluisen etal 1985).

Figure- 3 shows variation of dielectric constant $\left(\varepsilon^{\prime}\right)$ with temperature $\mathrm{T}(\mathrm{K})$. For the series of sample the variation in dielectric constant for temperature lower than $420 \mathrm{~K}$ is low, beyond this temperature there is rapid increases of the $\varepsilon$ upto $600 \mathrm{~K}$ and further increases in temperature, increases of $\varepsilon$ ' is low. This behavior of the temperature depended of the dielectric constant is similar to the hexaferrites observed by [32] Haberay 1968.

\section{Conclusion:}

The samples of vanadium YIG with composition of aluminium were prepared using solid-state diffusion technique. XRD pattern of the sample showed a single crystalline phase with a space group Ia3d in which garnets are found. The lattice parameter decrease by the substitution of $\mathrm{Al}+3$ and $\mathrm{V}^{+5}$ for $\mathrm{Fe}^{+3}$ in a YIG. Electrical conductivity of pure YIG is an ionic crystal having room temperature is below 10-3 ohm ${ }^{-1} \mathrm{~cm}^{-1}$ and substituted YIG show a mixed ionic-electronic conductivity. The activation 
energy is found to rise by increasing $\mathrm{Al}^{+3}$ for6. $\mathrm{Fe}^{+3}$.The temperature depended of the dielectric constant are behaves similar to the hexaferrites materials.

\section{References:}

1. Aleonard R 1960, J. Phys.Chem.Solids 15167

2. Balestrino and Geller S 1986, J. Phys.Chem.Solids 47 (10) 1013

3. Bertaut F and Pauthenet R 1957 ,Proc. IEEE B Suppl.104 261

4. Bouwen A J 1987 Digital Instrumentation, McGraw hill International Editions

5. Chatterjee S S, Prankishan and Laroja K K 1978, Comm. Indiam J.Pure and Appl. Phys. 16777

6. Crangle J 1977, The magnetic properties of solids, $1^{\text {st }}$ Edition, Willmer B.Ltd Mersayside, London

7. Geller S and Gilleo M A 1957, J.Phys.Chem. Solids 336

8. Geller S, Espinosa G P, Williams H J, Sherwood R C and Nesbitt 1963, J.Appl.Phys.Lett. 3(4) 60

9. Geller s, Williams H J, Sherwood R C and Espinosa G P 1964, J.Appl. Phys 35 (6) 1754

10. Goernert P, Simpsa Z, Sinsova J, Tomas I, Hergt R and Kub J.1986, Phys.Status Solidi A 95 (2) 613

11. Haberay F and Wijn H P J 1968, Phys. Status Solidi 2623

12. Hartmann E, Kovacs L and Paitz J 1984, Phys. Status Solidi A 8620

13. Hellstrom E E, Ray R D II and Zhang C 1989, J.Am. Ceram. Soc.72 (8) 1376

14. Henry N F M, Lipson H and Wooster n a 1953, The interpretation of $\mathrm{X}$-ray diffraction Photographs, McMillan London

15. International Tables for X-ray Crystallography 1967,Kynoch Press Birmingham Vol 1345
16. Langley R H and sturgeon G D 1979, J

Solid State Chem.30 79

17. Mestsellar R and Larsen P.K. 1978, Physics of Magnetic garnets (Edited by Paoletti A) North-Holand, New York 417

18. Okuda $\mathrm{T}$, Katayama $\mathrm{T}$, Satoh $\mathrm{K}$ and Yamamoto H 1991, J Appl.Phys.69 (8) 4580

19. Oversluizen $G$ and Metsellar R 1985, J Phys.Chem. Solids 46 (4) 455

20. Petrov S, CHomakov I and Bogdanov. B.J.1987, Cryst. Re.Technol. 22(6) 855

21. Powder Diffraction file, Joint Committee on Powder Diffraction standerds, International Center for diffraction Data, Swarthmore PA, ICDD-1990, card 33-40 and 33-693

22. Ramasastry C, Reddy K V and Murthy V S 1971, Proc. R. Soc. London Ser. A 328- 347

23. Rodic D, Tomkowicz Z, Novakovic L, Szytul A and Napijalo M L 1990, Solid State Commun. 73 (3) 243

24. Roschmann P 1981 J. Phys.Chem.Solids 42 337

25. Rotman S R and Tuller H L 1987, J. Appl.Phys. 62 (4) 1305

26. Rotman S R and Tuller H L 1990, Solid State Ionics 40-41 )Pt-2) 893

27. Salem M R and Elshereafy E 1994, J.Mater Sci. 29 (11) 2939

28. Shannon R D 1976, Acta. Cryst. A 32751

29. Shannon R D, Oswald R A, Allik T H, Damen J P M, Mateika D, Wechsler B A and Rossman G R 1991, J. Solid State CHem. 95(2) 313

30. Stadley K J 1972, Oxide magnetic materials (London: Oxford Univ. Press)

31. Takeuchi Y and Haga N 1976, Proc. Jpn.Acad. 52228 